\title{
HABITAR LA LENGUA QUE NOS HABITA
}

Sobre Kolic'Cecilia, Ferroggiaro Federico y Sarro Damián. Lengua I. Educación Media para Adultos. Editorial Dunken. Buenos Aires. 2015

¿Y qué decimos? ¿Qué hablamos? ¿Qué escribimos? Nada menos que el diccionario universal de las pasiones, las dudas, las aspiraciones que nos comunica con nosotros mismos, con los otros hombres y mujeres, con nuestras comunidades, con el mundo. La tierra existiría sin nosotros, porque es realidad física. El mundo, no, porque es creación verbal.

Carlos Fuentes, Conferencia Inaugural, III Congreso Internacional de la Lengua Española, Rosario, Argentina, 2004.

Lengua I. Educación Media para Adultos es un libro escrito por un equipo que se da a la tarea de fundar espacios bibliográficos necesarios para la práctica docente, así como para el proceso enseñanza aprendizaje en la escuela media en su modalidad para adultos. Dicha modalidad, desde su reglamentación hace ya más de cuarenta años en nuestra provincia, presenta particularidades curriculares que deben ser abordadas de manera integral y transversal por material didáctico pertinente, eficaz, accesible y transformador. Existe una dificultad corriente: los docentes de secundaria nos encontramos con manuales y libros de estudio que han sido elaborados, en su mayoría, por autores que no están frente a curso, y lo 
inadecuado del material "salta" inmediatamente. También es usual encontrar en circulación libros que han sido elaborados por editoriales de otras provincias, la mayoría de CABA, desconectados de las orientaciones curriculares santafesinas.

Lengua I aparece como un intento de justicia didáctica. Una necesidad de la práctica áulica. Un eslabón imperioso en los procesos secuenciados de búsqueda y construcción de espacios educativos propicios. Tal como aparece en las fundamentaciones de las Orientaciones Curriculares Provinciales "los recursos y planificaciones deben ser elaborados desde la vocación y la responsabilidad de idear una propuesta educativa para sujetos jóvenes y adultos que fueron, en muchas ocasiones, excluidos de los beneficios de la acción concientizadora, formadora y permanente de la educación, de parte de docentes comprometidos con la realidad que buscan mejores formas de llegar a la promoción humana de los estudiantes a través del conocimiento". Todo lo que parece haber sido motivo de reflexión y de consideración por los autores del libro que aquí se presenta.

Las políticas de inclusión educativa también son una cuestión de recursos didácticos. En el aula, el trabajo con material apropiado es una estrategia inapelable de accesibilidad a los procesos educativos y de participación activa por parte de los estudiantes. Pensar hoy en el sujeto que participa de la Educación de Jóvenes y Adultos implica focalizar la mirada no sólo en lo pedagógico sino también en las situaciones sociales desventajosas que inciden en el ámbito de sus relaciones y derechos. La EEMPA tiene el deber de plantear planificaciones, y luego los recursos que las particularicen, definidos por la especificidad de los sujetos que participan de ella, por las problemáticas concretas que los atraviesan y por la voluntad de plantear respuestas a sus necesidades. La posibilidad de aprender y participar de la experiencia educativa 
está, entonces, íntimamente ligada a la posibilidad de comprender el material que mediatiza dichos procesos.

En su aspecto formal, Lengua I propone una división en cuatro unidades, en torno a determinados ejes temáticos curriculares, que aglutinan otras problemáticas, tanto en lo teórico y lo crítico como en lo práctico.

La Unidad 1 bajo el título "Pido la palabra" instala un recorrido que parte desde el fenómeno comunicacional incluyendo el lenguaje no verbal-gestual, para pasar por la palabra, luego en su proyección textual; aborda la concepción de texto como unidad lingüística entramada por relaciones tales como coherencia, cohesión, funciones, y tipologías. Finaliza con un bloque de ejercitación que resulta reflexiva),en torno a la acentuación. Resulta destacable del capítulo la relación que se establece entre la lengua en su función comunicativa y otros sistemas semióticos tales como la fotografía, la pintura y el discurso audiovisual (se sugiere trabajar, por ejemplo, la cuestión del lenguaje no verbal a partir de un capítulo de la serie "Lie to me")

La Unidad 2 titulada "Mitos y leyendas ¿Una realidad desvanecida?", se estructura en torno a los relatos fundacionales de las diferentes culturas. El corpus propone el trabajo alrededor de mitos de la Antigua Grecia, articulándose de modo comparativo con leyendas locales, y relatos americanos, como es el caso del Popol Vub o libro sagrado de los mayas. En términos generales la unidad plantea una lectura crítica posible, pero se ve complejizada por algunas estrategias no del todo clarificadoras, tales como orientar la reflexión en torno a conceptos "inasibles", o postular diferencias entre mitos y leyendas a partir de un cuadro comparativo que desdibuja algunas cuestiones. No obstante, se apuesta a la comprensión directa de las fuentes y se introducen fragmentos 
de textos críticos que, ahora sí, completan de modo eficaz el sentido de la unidad (Levi Strauss, García Gual). En el plano semiótico del texto mítico se introduce y profundiza el análisis de los roles actanciales, y en lo gramatical, la unidad cierra con uso y reconocimiento de clases de palabras. Esto último ejercitado a través de estrategias de completar los blancos o inducir los vocablos, que se complejizan gradualmente para poder acompañar al estudiante durante el proceso de reconocimiento y diferenciación entre lo clasificatorio y las funciones sintácticas de las palabras dentro de la oración.

En la Unidad 3, "Periodismo y literatura. Una fusión entre ficción y realidad" nos encontramos con la problemática de la articulación de géneros y su coexistencia dentro de un mismo espacio textual. La reflexión es necesaria en función de desarticular la concepción aristotélica estanca acerca de los géneros literarios. Textos como la crónica periodística nos invitan a repensar las organizaciones textuales desde el punto de vista de la mixtura, donde informar, opinar y hasta poetizar se trenzan en la búsqueda de una narración que se distancia de la pretensión de objetividad y se acerca así, un poco, a la literatura. De este modo se abre paso en el capítulo el género policial, con su configuración particular y sus elementos característicos, cuyo exponente para la lectura y el trabajo ulterior es el cuento "Algo bien grande" de Osvaldo Aguirre, autor local, planteado también como una forma de estimular el encuentro entre los textos rosarinos y sus lectores. La unidad incluye, por último, un espacio normativo acerca de los signos de puntuación, y la propuesta de análisis sintáctico en el capítulo 7 de "Rayuela" de Cortázar.

La última unidad postula un trabajo completo y creativo de abordaje de la lengua española y sus problemáticas: ¿español o castellano?, lenguas de sustrato, latín y lenguas romances, los aportes musulmanes, etc. "Del latín al argentino rioplatense" 
como título, enuncia la voluntad de expandir la perspectiva geohistórica de nuestra lengua hasta llegar a la configuración de uso regional. "Las viejas lenguas eran vivas/cuando vibraban en la gente". Así introduce Mario Benedetti esta unidad, en la que se incluyen fragmentos textuales de Ivonne Bordelois, Carlos Fuentes y Antonio Tarragó Ros, entre otros. Son muy importantes en este último segmento del libro los paratextos (mapas, imágenes de documentos históricos, gráficos) al completar visualmente el sentido de los textos teóricos. El capítulo se subdivide en "Introducción", "El latín en la Península Ibérica", "Latín culto y Latín vulgar", "Las invasiones de los "bárbaros", "El aporte musulmán", "El castellano se estandariza", "El español en América" y "El lunfardo". Se intercalan ejercitaciones que permiten revisar los contenidos y avanzar con las lecturas.

En términos generales, por un lado, el formato elegido resulta práctico en el amplio y múltiple sentido de la palabra. El "tamaño libro" $(23 \times 16 \mathrm{~cm})$ aleja al texto de los usuales manuales de aula y podría pensarse la lectura-aprendizaje desde un lugar novedoso. Por otro, los autores han acertado en la mayoría de los casos respecto de la selección de textos, siendo los mismos convocantes y eficaces a la hora del trabajo áulico. Se vislumbra así, una vez más, la resonancia de las Orientaciones Curriculares Provinciales, que sugieren que los textos sean de interés para los alumnos, y que el docente actúe como facilitador en los casos en que la complejidad del texto demande su intervención. No se trata de "facilitar" los textos modificándolos, o de crearlos ad hoc. El contexto cotidiano aporta múltiple material de lectura con el que nuestros alumnos están familiarizados, aun cuando no puedan "leerlo". Con el correr de las páginas de Lengua I nos encontraremos con letras de tangos o canciones folklóricas, temas de Calle 13 o de Joan Manuel Serrat. 
El diseño y la diagramación de los interiores del libro es atractiva, minimalista y no escolar, pertinente en material para adultos. También resultan relevantes la incorporación del lenguaje digital y el uso de la web, ya que en cada unidad se sugieren recursos online para continuar las propuestas que presentan.

Todos los capítulos plantean una relación sumamente dinámica entre teoría y práctica, a la vez que ordenan los contenidos de modo preciso, ofreciendo un resumen temático al principio, y ejercitación integradora al final. Las ejercitaciones respetan el criterio de secuenciación, central en las propuestas de los NAP.

Estamos frente a un libro que estimula al tránsito didáctico de un desafío constante: habitar la lengua que nos habita. 